Meta

Journal des traducteurs

Translators' Journal

\title{
A History of Translation and Interpretation in Cameroon from Precolonial Times to Present
}

\section{Charles Atanganna Nama}

Volume 35, numéro 2, juin 1990

URI : https://id.erudit.org/iderudit/003694ar

DOI : https://doi.org/10.7202/003694ar

Aller au sommaire du numéro

Éditeur(s)

Les Presses de l'Université de Montréal

ISSN

0026-0452 (imprimé)

1492-1421 (numérique)

Découvrir la revue

Citer cet article

Atanganna Nama, C. (1990). A History of Translation and Interpretation in

Cameroon from Precolonial Times to Present. Meta, 35(2), 356-369.

https://doi.org/10.7202/003694ar d'utilisation que vous pouvez consulter en ligne. 


\title{
A HISTORY OF TRANSLATION AND INTERPRETATION IN CAMEROON FROM PRECOLONIAL TIMES TO PRESENT ${ }^{\prime}$
}

Charles Atangana Nama Buea University Centre, Cameroon

A comprehensive history of translation and interpretation in Cameroon from 1840 to present cannot be exhaustively discussed in a limited scholarly paper of this nature given the scope of data collected during field work for this project. Consequently, what follows is a synopsis of material synthesized analytically and tailored to meet the requirements of a learned journal.

Cameroon, officially alluded to as the Republic of Cameroon and popularly known in journalistic circles as "a microcosm of Africa and economic giant of Central Africa" owes its name to several historical and linguistic factors, amongst which is, coincidentally, an act of translation and interpretation. According to concrete historical evidence, when the Portuguese arrived in Cameroon in the fifteenth century, they were overwhelmed by the number of prawns which they saw in the Wouri estuary. As a consequence, they named it in Portuguese, Rio dos Cameroes which means "river of prawns". The Spanish version of this world, Camerones, was modified into the Anglicized name of Cameroons.

Scholars of Cameroon history, notably, Engelbert Mveng in Histoire du Cameroun and Victor Julius Ngoh, in Cameroon 1884-1985: One Hundred Years of History ${ }^{2}$ testify that English, French and German have at various periods been the official languages of Cameroon. This in effect means that these foreign tongues which still flourish in the country in varying degrees are the main European languages of translation and interpretation in Cameroon. However, it must be emphasized that English and French are the official languages. Cameroon's linguistic diversity is underscored by the fact that even though its population is approximately ten million, a myriad of languages, approximately 236, are spoken by different ethnic groups throughout the country. In A History of the Cameroon, Eyongetah and Brian remind us that:

\begin{abstract}
All the other known forms of speech in the Cameroon belong to a single great group of languages, which we know as Bantu. Traditionally, the Bantu language group in Cameroon is divided into two Sub-groups, Bantu proper, spoken in the Southern and South-eastern foreign plains (Douala, Fang, Bakweri are examples) and the semi-Bantu (Bantoid) languages spoken in the Western regions bordering Nigeria and the Central Highlands (Banyang and Bamileke). This broad division is convenient but it should not of course hide the fact that many of these "languages" within "language families" are very different and preclude any communications between speakers of different languages ${ }^{3} \ldots$
\end{abstract}

These language groups are further divided into sub-groups which are variants of the same language. For example, the Fang "language family" comprises the Ewondos, Etons, Bulus. The Fang-Beti who inhabit the Centre and South provinces of Cameroon extend to Gabon and Equatorial Guinea. 
A cursory overview of the linguistic diversity of Cameroon illustrates the horrendous problems of language contact and interference which the translator is bound to encounter in the exercise of his professional duties. Thus, the evolution of translation and interpretation in Cameroon from 1840 to present should be viewed from two perspectives, namely, work done in European languages and that done in national languages. Emmanuel Chia reminds us in A Sociolinguistic Profile of Urban Centers in Cameroon that "of the four major families into which Joseph Greenberg (1966) groups African languages, the Congo-Kordofanian, the Nilo-Saharan, the Afro-Asiatic and the Khoisan, only the last of these is not attested in Cameroon (p. 19). He further attests that some of the approximately 236 languages codified in these sub-groups are the main vehicles of communication among the local population. They are also the medium of instruction in Adult literacy workshops and agents of political and administrative directives to those administered.

Discussing language varieties in translation, Catford notes in A Linguistic Theory of Translation:

The concept of a "whole language" is so vast and heterogeneous that it is not operationally useful for many linguistic purposes, descriptive, comparative and pedagogical. It is, therefore, desirable to have a framework of categories for the classification of "Sub-languages" or varieties within a total language; that is idiolects, dialects, registers, styles and modes.

(...) In theory, a "whole language" may be described in terms of a vast inventory of grammatical, lexical, phonological and in some cases graphological forms, together with information about relevant substance (e.g. features of phonic substance utilized in the phonology), and statistical information (on relative frequency of forms, etc.). All of these may be said to constitute features of the language ${ }^{4}$.

Because of the colonial factor which impinged negatively on African historical and linguistic domains, European languages have paid a certain price in terms of their constituents as "whole languages" in the continent. As a result of the cross-fertilization which has taken place between African and European languages, creolized versions of these languages have flourished throughout the continent. In the case of Cameroon, Pidgin English and Pidgin French are dominant. In actual fact, interestingly, Pidgin English is a major vehicle of communication in quite a good number of West African countries. Loreto Todd testifies in Some Day Been Dey (1979) that Pidgin English possesses all the features of a "whole language" which Catford enumerates in the quotation cited above. By virtue of its seminal role in the linguistic evolution of Cameroon, Pidgin English is one of the main languages of translation and interpretation in Cameroon. Catholic missionaries, for example, have translated prayers and other religious messages from English into Pidgin English. On a cultural and artistic level, Pidgin English has been used on numerous occasions by writers to practise "creative translation" in order to reach a wider audience especially in the promotion of oral and written literature.

Empirically, it is appropriate to begin any serious study of the history of translation and interpretation in Cameroon from the precolonial period. This is a period when "natural translators" must have flourished in the country. From field work, it was discovered that "natural translators" flourish and still work in Cameroonian and European languages in several parts of Cameroon. A "natural translator" could be described as one who has not been exposed to a literate culture but possesses outstanding competence in languages and alien cultures outside his immediate environment. Consequently, in the midst of two or more individuals who have different linguistic persuasions, the "natural translator" acts as a mediator. Occasionally, they are literate but have no formal training as translators. The late Pa Lambert of Buea who served German colonizers, administrators and tourists 
for decades is an excellent example. Similarly, the late $\mathrm{Pa}$ Jacob who served the Catholic mission for almost half a century and Pa Nimang of the Fon's palace in Bafut are also cases in point. In actual fact, most of these "natural translators and interpreters" are found either in religious establishments, local and administrative units or royal courts. They deserve a special niche in the evolution of translation and interpretation in Cameroon.

Historically, it has been proven that the Sao civilization flourished in Northern Cameroon near the Lake Chad Basin between the fifth and tenth centuries. It seems to have been influenced greatly by Sudanic and Mediterranean cultural trends from the Nile Basin and probably Pharoanic Egypt. Even though this civilization seems to have ended in the sixteenth century and was only discovered in the twentieth century by archeologists, it is worth mentioning that some of their cultural artifacts such as pottery, copper, bronze, funerary urns, jewelry and even money made of clay with inscriptions have been discovered. In A Linguistic Theory of Translation, Catford notes that, "graphological translation is restricted translation in which the SL graphology of a text is replaced by equivalent TL graphology" (p. 62). In his classification of different kinds of translations, Catford underscores the significance of graphological translation in unravelling important information about different societies. Consequently, it would be interesting to explore the role that graphological translation has played and continues to play in the historical evolution of translation in Cameroon. In De la grammatologie, Jacques Derrida underscores the significance and major contribution of pictorial writing in any meaningful study of history, language and culture. In Spivak's translation of this seminal work, Jacques Derrida notes that, "the graphic form of words strikes us as being something permanent and stable, suited better than sound to constitute the unity of language throughout time, is that not a natural phenomenon too?" (p. 36). This "permanent and stable" nature of "the graphic form of words" which is timeless, has, undoubtedly, after the decodification process or rather, translation process, unravelled a lot of information in all societies where such pictorial writing thrived. Such a scholarly method of translation of "graphic texts" of the Sao age in Cameroon and other historical epochs has filled a void in the precolonial history of Cameroon.

In this regard, it is imperative to mention that in Histoire du Cameroun and L'art et $L$ 'artisanat africain, Engelbert Mveng, S.J. has documented the pictorial writing language of most Cameroonian ethnic groups similar to that found in several African cultures. Like the architects of the Nok civilization in Nigeria, whose artists were gifted in the graphic arts, in Cameroon, the Bamoun, Bamileke and Betis among others have established their reputation or mastery of the arts in this domain. Interestingly, this scholarly kind of translation which entails the decodification of these "graphic texts" has already begun. It is pioneered by one of Cameroon's leading scholars and translators, Father Engelbert Mveng, S. J. He has decodified several of these "graphic texts" and informs us about the results of his "graphological translation" of a very popular artifact among the Betis of Cameroon. As a result of his study, the abbia motif, popular among the Betis, based on the pictorial and graphic writing, when deciphered has several meanings in Beti culture:

1) abbia means Nka'a: la salamandre 2) abbia means yengis: morceau de tissu d'autrefois 3) abbia means kabat: l'agneau 4) abbia means eyel onon: l'oisillon 5) abbia means ndig: une grosse liane 6) abbia means o-bog minkumba: oiseau logeant dans les troncs d'arbre.

Examples of this method of scholarly translation - the decodification of African "graphic texts" from precolonial to contemporary times is an important contribution in the evolution of translation historically and theoretically.

In the precolonial and postcolonial periods, the history of translation in Cameroon must, of necessity, be viewed from the following perspectives: religious, literary and 
technical. The clash of cultures between Cameroon and the West unquestionably contributed immensely to the paramount role of translation and interpretation in the society.

From a religious standpoint, with the advent of Western forms of worship in the late nineteenth century, communication between the apostles of the new faith and the indigenes whom they wanted to convert very badly was inevitable. Four major religious denominations namely, Islam, Roman Catholicism, Presbyterianism, and Baptists were among the first to infiltrate the country. While Islam had a stronghold in the North, the other three religions established their headquarters in the South. Their objectives were the same - to propagate the faith.

From a historical perspective, Victor Julius Ngoh reminds us in Cameroon 18841985: A Hundred Years of History that the Baptists were among the very first missionaries who arrived in Cameroon in the middle of the nineteenth century. Amongst the pioneers were Joseph Merrick, Alexander Fuller, Rev. John Clarke of Jericho, Jamaica and Dr G.K. Prince. Of these courageous ecclesiastics, Rev. Joseph Merrick, a Jamaican of African ancestry, can be credited as being one of the pioneers of translation and interpretation in Cameroon. He was part of the missionary expedition which arrived in Cameroon in 1843. During his brief but fruitful sojourn in Cameroon, Rev. Merrick studied Isubu, the language of the coastal, proud Bimba people, veteran sons of the sea. He then embarked on a gigantic translation project - translating part of the New Testament into Isubu. In addition, he also studied Douala and translated the Bible into that language. $\mathrm{He}$ is also credited with working on a Douala-English terminological glossary. Even though he died early and young, on October 22, 1849 on his way to England, Rev. Joseph Merrick's accomplishments in the fields of evangelization and translation and interpretation were appreciated by his successors, that is the Baptist Mission in Cameroon, which honoured him by naming Joseph Merrick Baptist College in Ndu, in the North West Province of Cameroon in his honour.

Another Baptist missionary, Rev. Alfred Saker who arrived in Victoria, now Limbe, one of the coastal towns in Cameroon, in 1858, can be credited as being one of the earliest "missionary translators" in the historical evolution of the profession in the country. Like his predecessor Rev. Joseph Merrick, Alfred Saker studied the Douala language and translated the Bible into it. Saker's accomplishment was controversial. However, he succeeded partially in conveying the gospel to the indigenes in their own language. Contemporary linguists, scholars and missionaries who work in the Douala language who met during field work dismiss Saker's translation as being too literal and sloppy in the sense that like the Belles Infidèles of the nineteenth century in Europe who espoused word for word translation, he was faced with what Nida describes in Language, Structure and Translation as "acute problems which confront any Bible translator", such as translating expressions which relate to behaviour e.g. "beating the breast; semantic patterns e.g. repetition of constituents and idiomatic expressions. Despite the rather harsh condemnation of Saker's translation of the Bible into a Cameroonian language, it is important to note that other translators working in the area confronted and still confront similar problems. Nevertheless, his translation into Douala of the New Testament was published in June 1862 and the Old Testament in February 1872. Two major works, The Pioneers and A History of the Presbyterian Church in West Cameroon by Werner Keller indicate that what is generally known in Cameroon today, that is, in English-speaking Cameroon as the Presbyterian Church was a hundred years old on the 23rd of December, 1986. It is important to make this distinction because according to another authentic source, Bernard Omgba's Histoire de l'Église du Cameroun 1841-1982, another Presbyterian group of missionaries, known as the American Presbyterian Mission led by Dr A.C. Good arrived in Cameroon in 1885 and founded a mission at Efoulan in 1893 and another one in 
Ebolowa in 1895. These missionaries who worked in the Francophone part of the country, in what is known as the South Province of the Republic of Cameroon, should not be confused with the Presbyterians who came principally from Switzerland and Germany and established in the English-speaking section. What unifies these two Presbyterian denominations in Cameroon is that both of them contributed immensely to the historical evolution of translation and interpretation in Cameroon in the sense that they produced the earliest "missionary translators" in the country besides their Baptist, Catholic and Islamic counterparts.

The German missionary Dr. Adolf Vielhauer (1880-1959) and an indigenous Cameroonian teacher and preacher, Elisa Ndifon (1888-1971), ably assisted by a team of native Mungaka speakers and Anna Hummel and Elizabeth Buhler, translated the Bible into the Cameroonian language Mungaka. It took thirty years to complete the entire exercise, although it must be mentioned that the second world war contributed to the prolongation of the work. After a brilliant university education at Heidelberg, Halle, Berlin and Tübingen, Adolf Vielhauer was posted to Cameroon in 1906. On his arrival he was sent to Bali where, thanks to his linguistic abilities, he immersed himself in a serious study of their language Mungaka. After some time he had grasped the language so thoroughly that he was able to make the following observations about the language:

The Bali tongue is a Bantu language, strongly influenced by Sudanese elements; as the Bali have immigrated from the North into their present place of residence they have given up their old Sudanese language (Mubako) and taken over from their neighbours a Bantu dialect.(..) nouns in Bali language have neither a definite nor an indefinite article; that there is no declension in the sense of European languages and that most nouns have no special form for the plural... 5

Apostles of contemporary translation theories, particularly those who embrace linguistic-oriented theories, and advocates of such concepts as fidelity to the original and problems of dynamic and textual equivalence will find these observations by Dr. Vielhauer useful which he made in 1956 based on his experiences of translating the Bible from English into Mungaka, a Cameroon language.

He writes:

... it is my earnest desire to render and translate biblical truths as accurately as possible, but in such a form and language that the readers in the grassfields of the Cameroons get the impression that Moses and the Prophets, the Saviour and the Apostles had been people of the grassfields, had lived and worked among them...

The Cameroonian languages into which Dr. Vielhauer and Elisa Ndifon, Rev. Joseph Merrick and Rev. Alfred Saker, amongst others, translated the bible are generally referred to as LLD (Languages of Limited Diffusion) by the International Federation of Translators. Some of the problems raised by Vielhauer are discussed in detail by Gyorgy Rado and Elena Nikolova in Babel (1987, XXXIII: 6-14). They confirm Vielhauer's theory that, in order to convey the message of the text successfully, environmental adjustments have to be made linguistically even if a slight distortion of the original has to be made. In this connection, translation become interpretation. The following illustrations convey the point.

Many animals mentioned in the Bible do not exist in Cameroon, like the bear, the wolf, the fox, the camel. For wolf and bear, Vielhauer and Ndifon used leopard; and for the camel, elephant. Several biblical plants were substituted. For wheat they used maize, barley, millet, mustard seed, pepper; for vine, they invented wine tree. The Mungaka language into which they translated the Bible lacks words for such abstracts as the light, the 
good, truth, honesty, faithfulness, love, hope, etc. Consequently, "I am the light of the world". Mathew 5: 14-16 reads in part, "you are the torches in the world... nobody lights a lamp" was rendered as let your fire shine into the eyes of the people". Leviticus 19:2 partly reads "you shall be holy...". It was translated as "you shall be perfectly good, for I, Yahwe, your God, am perfectly good". This adaptation by Vielhauer and Ndifon no doubt made the message more accessible to the local population.

Dr. Vielhauer's contributions to the historical and theoretical evolution of translation and interpretation in Cameroon is symptomatic of the immense contributions made by missionary translators in particular and the German colonial administrators in general. Between 1909 and 1952, this prolific translator published the following works in a Cameroonian language, Mungaka:

1. Tsu mutin (sermon outlines) 56 Old Testament and 83 New Testament (1913)

2. Nu Nikob ma nwa'ni Nden Kan ni Mfi 1915 (Bible Stories Revised 1930)

3. Grundzüge einer Bali Gramatik 1915 Elements of Bali Grammar

4. Tsu mana $1909 / 10$ Parables

5. Nwa'ni déobntsi 191047 hymns; 1923 (57 hymns) 1930 (70 hymns)

6. Marko and Roma (1929) Mark and Romans

7. Kan Mfi (New Testament) 1933 revised 1958

8. No'u Nku'mu 1939 (Church Constitution)

9. Nu a ka ndze nku'mü bun-kristo kumvi a 1944 Church History

10. Nwa'ni Psalm ni tsu Ba'ni 1949 Psalms

11. Nwa'ni Yesaya bo i Yeremia 1952 (8) Isaiah and Jeremiah.

When the University of Heidelberg awarded him a doctorate degree (honoris causa), it was because of his accomplishments as a missionary and translator in spreading the gospel. Even though Dr. Vielhauer did not live long enough to see the publication of the entire Bible, his contribution in the field is remarkable.

It will be misleading to conclude that most of the missionary translators who pioneered the profession in Cameroon were foreigners. Eugene Nida's thesis that the best translations, especially those concerning LLDs (Languages of Limited Diffusion) are done in groups accurately describes the manner in which the profession evolved in Cameroon. An excellent example is the collaboration between Dr. Vielhauer and Elisa Ndifon (1888-1971) in undertaking translation projects of religious and literary material into national languages, specifically, Mungaka. Elisa Ndifon made two trips to Germany in September, 1931 to work with Dr. Vielhauer on the project of translating the Bible into Mungaka. After two years'duration, their team work resulted in the publication of the New Testament in Mungaka in October, 1933. In March, 1954, Elisa Ndifon was invited to Germany to work on the Old Testament. He returned twenty months later. With 
Dr. Vielhauer's death in 1959, Elisa Ndifon continued working on the bible translation with Rev. G. Tischauser and Heidi Hummel. The translation of the whole Bible into Mungaka was published in 1961.

Besides Baptist and Presbyterian missionary translator/interpreters who pioneered the profession in Cameroon, the early Roman Catholic missionaries also made some major contributions. In Histoire de l'Église du Cameroun 1841-1982, Bernard Omgba informs us that even though German missionaries stayed in Cameroon for a very short period they made tremendous contributions to the evolution of translation and interpretation in the country. From all indications, the German missionaries like the Presbyterians and Baptists had a well-established translation service in the country. It is significant to underscore the fact that the formal training of translators and interpreters in Cameroon was started by German missionaries. Interestingly, the first Roman Catholic Christian baptized in Cameroon, André Mbangué, was among the pioneers to be educated in Germany who later on contributed to the development of the profession. In Histoire de l'Église du Cameroon 1841-1982, Bernard Omgba writes:

En 1888, trois jeunes gens de Douala, qui avaient pour nom Akwa Mpondo, Timba et Mbangué étaient envoyés en Allemagne par un commerçant allemand établi à Douala pour y apprendre le métier de boulanger. C'était le tout premier groupe d'étudiants camerounais envoyés en Allemagne... André Mbangué c'était désormais son nom, était le premier chrétien catholique du Cameroun.

(...) Dès que nous entendions parler de leur arrivée, raconte le père Walter, nous les invitâmes à venir à Marienberg et à Edéa. Ils nous rendirent grands services pour la traduction en langue douala du catéchisme et de l'Évangile, ainsi Andréas se rangea-t-il aussitôt aux côtés des missionnaires et des premiers apôtres camerounais dont il devint le chef de file pour travailler avec eux à l'évangélisation de ses frères 8 .

André Mbangué did not only serve as a translator but also as an interpreter in the sense that as a catechist, while preparing Christians for the sacraments he interpreted religious dogma to them. The early German missionaries understood the pivotal role that catechists played and still play in disseminating the gospel as interpreters. That is why, immediately after their arrival in Cameroon in 1890, the German Pallotine Fathers led by Monsignor Henri Vieter opened a junior seminary in Einsiedeln (presently known as Sasse) in 1907. In addition to their ecclesiastical training, at Einsiedeln the future catechists were taught German and Pidgin to enable them to communicate effectively with the masses or congregation. By the time the Germans left Cameroon in 1915, 223 catechists had graduated from the junior seminary in Einsiedeln. Some of these graduates, amongst them, Joseph Ayissi, Pierre Mebe and Pius Ottou underwent further linguistic training in Hamburg, Germany. On their return home, they were charged with the responsibility of translating the Missal - a Catholic Prayer book - from German into Ewondo. They translated it as Kalara Ngogelan.

In Histoire de l'Église du Cameroun 1841-1982, Bernard Omgba reminds us that the Roman Catholic Church in the country is divided into four ecclesiastical provinces and sixteen dioceses. In each of these provinces national languages are the main vehicles of communication with the masses rather than English and French. That is why with the advent of the missionaries, national languages played a dominant role in the dissemination of religious dogma. One of the earliest missionary translators who played a major role in promoting the teaching of the gospel to the inhabitants of one of the main ecclesiastical provinces in the country, that is the centre province where Ewondo, Bulu among others are the main languages, is Monseigneur Vogt (1870-1943), a master of languages, he knew German, French, Latin, Ewondo and Pidgin. In the field of translation, he produced 
one of the first "best sellers" in the country by publishing a bilingual Ewondo/French religious book in 1925 entitled simply Syllabaire Ewondo/Français. It contained translations of religious dogma, historical information in both languages and even brief grammatical guidelines on the two languages. Because of its diversified content, within ten years, 10,000 copies were printed in six editions.

Monseigneur Vogt is also one of the pioneers of interpretation in the country. During field work, I was reliably informed by Père Nicolas Ossama of the Cathedral at Mvolyé that Mgr. Vogt insisted that all new missionaries must master Ewondo, one of the main languages of interpreting the gospel to the masses. On arrival, each new missionary was taught the language for six months, after which he was subjected to an oral and written examination, conducted by Mgr. Vogt himself. Those who were not successful had to sit for the examinations again until they were successful.

The Second Vatican Council was a milestone in the history of the Catholic Church in Africa in the sense that some of the traditional, conservative concepts of the Church were modified slightly. In 1965 the Holy See authorized the Africanization of the Church, in the sense that the Holy Mass could now be said in African languages. Traditionally in the past, it was done in Latin. This unprecedented move by the Vatican had an impact on translation in Cameroon. Even though some attempts had been made in the past to translate religious dogma into Cameroonian languages, as far as the Catholic Church in Cameroon is concerned, the second half of the twentieth century, from the late $60 \mathrm{~s}$ to be more precise, was the "golden age" of translation into national languages.

The architect of this resurgence of translation activities was Abbé Theodore Tsala, a distinguished scholar and translator in his own right, also known for his translations of the Cameroonian epic poem, the Mvet from Ewondo into French. Abbé Tsala began translating the Bible into Ewondo. At this juncture, it is imperative to state that from a comparative perspective, the Presbyterian missionaries who arrived in French-speaking Cameroon and specifically in the 1890s translated the bible into Bulu, another Cameroonian "Beti family" language. It was published as mfufub Bible. Nevertheless, as far as the Catholics were concerned, Abbé Tsala did not succeed in translating the entire Bible into Ewondo. He translated the First Book of Samuel, the Prophets and a few other Évangiles.

Private individuals, all of them ecclesiastics, have embarked on translating the Bible into Ewondo. Abbé François Amara has translated the complete missal and most of the New Testament into Ewondo. Père Nicolas Ossama has also translated a Catholic prayer book into Ewondo, entitled Kalara Mes. He has also translated excerpts of the New and Old Testament. The most ambitious translation project by the Catholics in the country to date is led by Abbé Anaya Noah of Collège Noah in Mbalmayo, a small town near the capital city of Yaoundé. It comprises, Abbé Noah of Mbalmayo, Père Nicolas Ossama of the Cathedral at Mvolyé, Abbé Anya, Abbé Kuma and Abbé Leon Messi. This project, started in 1985, so far promises to be the best team-work translation of the Bible into Ewondo. The first five books of the Bible have been translated and revised. During conversations with Père Nicolas Ossama, he confided that they meet occasionally at Mbalmayo to review and edit sections translated by the team translators. It is anticipated that this project of translating the Bible into Ewondo will be completed soon. The team has received a subvention from a philanthropic organization to enable it to complete the project.

Translation of the Bible into Bulu, another Cameroonian language, is headed by Abbé Zé, Rector of the Major seminary at Nkolbisson, near Yaoundé. Abbé Zé was instigated in part by the serious misrepresentations and distortion of facts by the early Protestant missionaries whose word-for-word translation of the Bible into Bulu was 
incomprehensible. The Catholic Missal has also been successfully translated into Bassa, another Cameroonian language, and published in 1970.

In the evolution of the history of translation and interpretation in Cameroon, philanthropic organizations have played a major role. Their contributions are best epitomized in the translation activities carried out by the Summer Institute of Linguistics, popularly known as SIL which started operating in Cameroon in 1969. The following statement partially summarizes its objectives, "through linguistic research and practical service, members of SIL serve the linguistic groups of the world, especially where the language has no written form and where there does not yet exist a translation of biblical texts in the language". (p. 88). It is estimated that there are approximately 5,500 SIL members working in about 40 countries, including 18 in Africa.

In Cameroon, SIL can be credited with having one of the best-equipped and wellfinanced translation centers in the country. SIL's translation service is unique in several ways, amongst which is the fact that it is working in 25 Cameroonian languages, translating the Bible into these languages. It occasionally organizes translation workshops in different parts of the country and emphasizes, "the translation of ideas unknown to a given culture, the translation of specific biblical terms and grammatical analysis". It has produced books and translated sections of the Bible into more Cameroonian languages than any other translation service in the history of Cameroon.

Another philanthropic prominent translation service in the country which has contributed immensely to the growth of the profession in Cameroon is the Gbaya Translation Centre at Meiganga in the Adamawa province of Cameroon. Like SIL, it is very well organized and has been operating in Cameroon for at least fifteen years under the auspices of the Alliance Biblique and the direction of the renowned American linguist and scholar, Professor Philip Noss. It has also published several books in Cameroonian languages.

Even though literary translation into European languages is still a novelty in much of sub-Saharan Africa and of course Cameroon, it must be mentioned that it is an important area of translation and interpretation in Cameroon. It is important to make some clarifications here. The main linguistic service in the Presidency of the Republic of Cameroon, which handles official translations of government documents such as presidential decrees, administrative and economic texts, does not or rather scarcely handles literary translation in Cameroon. Several factors are responsible for this state of affairs: firstly, these "civil servant translators" are too few in number, officially less than 150 throughout the country; secondly, analyses of questionnaires and interviews conducted during field work indicate that with the exception of a few, most of them have not acquired the rigorous training necessary to undertake this special kind of translation. Consequently, as far as literary translation in Cameroon is concerned, there is not a single professional "civil servant translator" who has translated and published a literary work by a Cameroonian artist. This sounds embarrassing and in fact incredible given Cameroon's unique bilingual status in Africa and the unprecedented prolific sensibilities of Cameroonian artists who, by and large, have been the most astute ambassadors of Cameroonian culture to the rest of the world.

This benign neglect of such a major cultural domain by "civil servant translators", does not mean that literary translation of Cameroonian works has been in the doldrums. Far from it. At this juncture, it is imperative to indicate that the translation of several Cameroonian works of art from European languages, principally French into English, has been done almost exclusively by foreigners, notably, Richard Bjornson of some of René Philombe's works, John Reed of Ferdinand Oyono's, Joyce Hutchinson of Francis Bebey's and Gerald Moore of some of Mongo Beti's. A few attempts have been made by 
Cameroonian graduate students at home and abroad to translate excerpts from works by Cameroonian writers into English in fulfillment of partial requirements for their diplomas in translation but as of now, none has translated a work of art completely and published it. Perhaps it is encouraging to indicate that Cameroon's best known playwright who works in French, Guillaume Oyono Mbia, is the only Cameroonian artist who has successfully translated some of his works into English and had them published. Even though the "Association Nationale des Poètes et Eccrivains Camerounais" was founded in January, 1960 , it does not have a strong translation section to promote literary translation like its counterparts in other countries.

Nevertheless, this gloomy portrait is partially representative in the sense that even though there is a paucity of Cameroonian literary translators who work in European languages, that does not hold true for works in Cameroonian languages as well. It is also imperative to indicate that men of letters in Cameroon, as in other African countries, have played a major and decisive role in the history of translation and interpretation in Cameroon, similar to their counterparts in the Western World, as testified by Louis Kelly in The True Interpreter: A History of Translation Theory and Practice in the West and George Steiner in After Babel: Aspects of Language and Translation. With the exception of "missionary translators" such as Joseph Merrick, Alfred Saker, the Pallotine Fathers, the Mill Hill Fathers and the Rev. Dr. Vielhauer whose numerous works in Cameroonian literature and culture were translated, there were several Cameroonians educated by missionaries who translated masterpieces into Cameroonian and European languages.

Of all the major personalities who played a dominant function in the history of translation and interpretation in Cameroon in national languages, Sultan Njoya of the Bamoun Kingdom is the most outstanding. This distinguished patriot enjoys such a special place because of his unique contributions. Patrice Kayo in Panorama de la littérature camerounaise writes:

La littérature camerounaise est née en langue bamoun, et c'est le sultan Njoya qui en est le pionnier. Pour rédiger ses œuvres, il a inventé sa propre écriture. On peut situer la naissance de cette littérature en 1895, date de l'invention de l'écriture bamoun... Aidé de plusieurs notables de son royaume, il créa les premiers signes. Chaque signe représentait un mot entier. Il aboutit ainsi à plus d'un millier de signes différents... Il se remit à l'cuuve et après une vingtaine d'années, des 1300 signes du début, l'écriture bamoun n'en comptait plus qu' une trentaine ${ }^{10} \ldots$

Sultan Njoya's exploits did not just end with the discovery of the alphabet and shiimon writing but he also invented a printing press. His Highness' writing was used for approximately ten years during his reign to record birth certificates, court judgements and interestingly, he himself used it to produce several literary and scientific works. Patrice Kayo reminds us succinctly in his work cited above, "... l' œuvre littéraire de Njoya est cependant la seule créée en écriture bamoun. Elle comprend notamment le livre de l' histoire et des coutumes bamoun, un livre religieux et un livre de médecine" (p. 51). The sultan's son Dr. Adamou NdamNjoya in NJOYA: Réformateur du royaume bamoun indicates that his father's monumental work, originally written in Bamoun language, which celebrates the literature and culture of his people, has been translated into French as L'Histoire et coutumes de Bamoun. Consequently, Sultan Njoya's pivotal role in the development of translation and interpretation in Cameroon is analogous to that of Joaquim Dias Cordeiro da Matta in Angola and Okot p'Bitek in Uganda.

Besides Sultan Njoya, the early "missionary translators" in Cameroon also collected and translated Cameroon oral literature. In this context, one of the most brilliant translators whose contributions have carved a special niche for him in the history of 
translation and interpretation in Cameroon is the German missionary, Dr. Vielhauer. Paying glowing tribute to this outstanding translator, Rev. Dr. Jonas Dah writes in African Responses to Christian Presence:

... Vielhauer distinguished himself in the Cameroon mission especially in literary work. In 1933 he gave the Grassland, the New Testament in Mungaka (Bali) which he had started to translate in 1931. In the same year of publication, Vielhauer was awarded an honorary Doctor of Theology by the University of Heidelberg ${ }^{11}$..

Dr. Adolf Vielhauer was assisted in the development, promotion and use of Mungaka as a principal vehicle of communication by another indigenous Cameroonian translator of note, Elisa Ndifon (1888-1971). Even though Dr. Vielhauer's legacy as a promoter of Cameroonian culture especially in the religious domain is remarkable by the vast number of works published between 1911 and 1952, it is important to mention that between 1909 and 1910 he collected and published important material in oral literature, notably parables in Mungaka. Eyongetah and Brain in A History of Cameroon confirm the seminal role of Mungaka as one of the most developed indigenous literary vehicles of communication in the North West province in Cameroon.

In his authoritative work, Histoire $d u$ Cameroun, the Jesuit priest Fr. Englebert Mveng, himself one of Cameroon's leading intellectuals and scholarly translators, traces the evolution of Cameroonian history, culture and indigenous languages. Fr. Mveng's observations are significant in the sense that they illustrate the role early writers played in the evolution of translation and interpretation in Cameroon. Given his analyses, it is evident that during the colonial era, German and French colonial eras to be more precise, several writers who were proficient in languages were recruited by the colonial administrators as "écrivain-interprète".

Underscoring the contributions of the "écrivain-interprète" during the colonial period, Patrice Kayo discusses their roles as writers, administrators, translators and interpreters. Analysing their functions, Kayo remarks on the most outstanding, notably Moumé-Etia and Louis Marie Pouka. In Panorama de littérature camerounaise, Kayo writes:

... En 1930 paraît en français et en douala un recueil de fables intitulé Fables Douala. La version douala en garantissait l'authenticité. Le signataire de ce fascicule, Isaac MouméEtia, écrivain-interprète formé à l'école allemande, était de l'élite intellectuelle de son pays, dont l'administration française s'était servi dans sa campagne d'implantation après la défaite et la capitulation de l'Allemagne... Il apprend à lire et à écrire en douala. Un an après, en 1900, il revient à l'école officielle où il est reçu en 1905 au certificat d'études primaires. C'est alors qu'il entre dans l'administration allemande en qualité d'écrivain-interprète, poste qu'il gardera même sous l'administration française ${ }^{12}$...

Another major Cameroonian artist who became an "écrivain-interprète" in 1931 is Louis Marie Pouka who worked for the French colonial administration before proceeding to Bordeaux to read law. It is evident from the functions of these "écrivain-interprète" in the colonial era that unlike professional translators in Cameroon today who are restricted to working exclusively on administrative, economic and socio-political texts, they functioned as administrators, translators, interpreters and creative writers working in both African and European languages. This distinction is important for several reasons. It indicates that the forerunners of this profession in Cameroon during the colonial era fulfilled several roles working in two distinctively different media with different linguistic structures. Moumé-Etia for example, worked in Douala, German and French. Interviews conducted with some elderly administrators who worked in the colonial era in the littoral province 
of Cameroon around Douala reveal that in addition to their administrative, bureaucratic chores, these "écrivain-interprète" accompanied their bosses on tours and performed as professional interpreters. Today, the "écrivain-interprète" in the tradition of Moumé-Etia and Louis Marie Pouka is quite a rare bird indeed, at least in this particular realm of a multi-talented artist and professional.

In the evolution of the history of translation and interpretation in Cameroon, the "écrivain-interprète" should be given a special niche. With the dawn of independence in 1960 , they were not swept away by the tides of independence. It is true that as a matter of historical fact, the prestige and power of the "écrivain-interprète" has dwindled considerably. In reality, he is almost an endangered species but he is found in various forms in royal palaces and traditional courts. The legendary $\mathrm{Pa}$ Nimang of the Fon's palace in Bafut falls into this category. Perhaps the best known "écrivain-interprète" of this postindependence epoch in Cameroon is the late Professor Bernard Fonlon. After an abortive bid for the Catholic priesthood, he proceeded to the National University of Ireland where he earned a Ph.D. in Comparative Literature. He also studied at Oxford and the Sorbonne. He returned to Cameroon at the dawn of independence. It was partially because of his fascination and exceptional mastery of languages that the former president, Ahmadou Ahidjo made him his personal interpreter. In the early 60s, Professor Fonlon accompanied the former president on several tours throughout the country. I witnessed a spectacular scene at Buea Stadium, jammed with people of all walks of life, during which President Ahidjo addressed the audience in French and his interpreter conveyed the message simultaneously in pidgin English, the Lingua Franca of the majority of the people. The applause was deafening. On another memorable occasion, in the Professor's native village, the former President's message was conveyed from French into Lamnso, the language of the people. It is evident that in the tradition of his precursors such as Moumé-Etia and Louis Marie Pouka, Professor Fonlon reinvigorated the major function of the "écrivaininterprète" in Cameroonian society. He distinguished himself in most of the texts he translated from French into English. In After Babel, George Steiner, discussing the method of translation used by the remarkable poet-translator Holderlin, indicates that the translator's methodology was so thorough that the final version he produced was almost a rewriting, an interpretation of the original which was better than the original. He writes:

... In modern hermeneutics the poetry, letters and translations of Holderlin occupy a privileged place... With a vehemence which carried him beyond the metaphoric, Holderlin came to regard all writing as a translation or transcription of encased, hidden meanings. Holderlin uses the figura etymologica (the reinterpretation of the meaning of words according to their supposed etymology) as does Heidegger: he is seeking to "break open" modern terms in order to elicit their root-significance ${ }^{13}$.

Professor Fonlon's place in the annals of translation and interpretation in Cameroon is secure. A master of languages (Latin, Greek, English, French, German and his native Lamso), in several of his essays on language, politics and culture and his scholarly journal Abbia, this "écrivain-interprète" distinguished himself as an etymologist and accomplished translator and interpreter. Like Holderlin, he saw all writing as a "translation or transcription of encased hidden meanings which had to be interpreted"; that is why his translation of the Cameroon national anthem and other texts from French into English were so thorough and so widely appreciated and admired that the original French version had to be revised.

Another area in the history of translation and interpretation in Cameroon which contributed to the historical evolution of these twin professions in the country is the enormous work being done with administrative and socio-political texts. Since the English- 
speaking and French-speaking parts of the country became a unified territory in 1972, and English and French automatically became the official languages, the volume of translation and interpretation activities of administrative and socio-political texts has increased dramatically. The linguistic services of the Presidency of the Republic, the National Assembly and a handful of government ministries and state corporations have professional translators and interpreters who, by and large, were educated in Schools of Translation and Interpretation in Europe and North America. They are strictly speaking civil servants confined to their bureaucratic pidgeon holes and they work almost exclusively on official documents. In 1985, a School of Translation and Interpretation opened its doors at Buea University Centre which trains translators and interpreters who work in English and French.

It is inaccurate to contend that the translation and interpretation of administrative and socio-political texts in Cameroon began in the 1970s after reunification. In actual fact, what goes on in this domain today is squarely and simply a continuum of work begun in the colonial era especially by the Germans in the early part of the twentieth century, around 1907, who by all indications had one of the earliest and best translation services in the country.

From a theoretical and artistic standpoint, an analysis of questionnaires filled out by civil servant translators who work in the government services indicated above has some astonishing revelations. In terms of methodology of translation, it seems as if the government-employed translator who handles official texts has very little room for creativity. He is duty bound to convey an "official tone" from the original to the target text. This "official tone" of the translated text had already been established by his predecessors and must be reflected in his translation. Secondly, the "official terminology" must be conveyed in the translated text. Unlike the translation of religious texts where some form of adaptation and interpretation is necessary to convey the meaning of the original text, in this kind of translation, the translator must conform to the spirit and official nature of the original text or he is lost completely.

In the history of translation and interpretation in the West and in Africa, terminology has always played an indispensable role. Similarly, in Cameroon as far back as 1840, the early missionary translators such as Joseph Merrick, Alfred Saker, Sultan Njoya of the Bamoun among others compiled bilingual terminological glossaries in European and Cameroonian languages to promote and facilitate translation and interpretation activities.

A modern terminology bank does not exist in Cameroon today, that is, compared to what is found at the EEC or the United Nations in New York. The linguistic service of the Presidency of the Republic publishes a few leaflets occasionally in terminology, but it is inaccurate to say that it has a terminology bank.

On the contrary, private, philanthropic organizations such as Summer Institute of Linguistics (SIL), Alliance Biblique and other religious denominations who have been at the vanguard of translation and interpretation activities in Cameroon have compiled and are still compiling terminology banks with the most modern technological gadgets. The best of these banks are in Cameroonian languages and cover a broad spectrum of subjects ranging from traditional African medicine, letters, religious data to modern scientific developments.

Contemporary research and scholarship attach much importance to the dissemination of knowledge through seminars and conferences organized by professional associations and the publication of scholarly journals. At the moment no professional organization of translators and interpreters exists in Cameroon. There is no evidence that one existed in the past. Similarly, there is no scholarly journal devoted to translation studies and research in Cameroon even though there is enough evidence to prove that the 
profession has thrived in Cameroon for quite some time. Nevertheless, it is imperative to indicate that two indigenous journals NLEB BEKRISTEN (translated as Guide des chrétiens) published in 1936 at Mvolyé (Yaounde) and Mafoe: le miroir des protestants were instrumental in publishing translated versions of the Bible or religious dogma in national languages for the consumption of the faithful. NLEB BEKRISTEN, for example, which occasionally printed about 7000 copies, published translations of versions of the Bible into Ewondo, one of the national languages.

In conclusion, in the evolution of translation and interpretation in Cameroon from precolonial times to present, a variety of factors such as linguistic development of national languages, political considerations, the spread of the gospel among others have contributed to the promotion of these twin disciplines in the country. The contribution that the historical development of the profession has made to translation theory and terminology research are discussed in depth in Okyeame: A History of Translation and Interpretation in Africa: A Case Study of Cameroon.

\section{NOTES}

1. This is an excerpt from a book in progress, Okyeame: A History of Translation and Interpretation in Africa: A Case Study of Cameroon (forthcoming)

2. Victor Julius Ngoh (1987): Cameroon 1884-1985: One Hundred Years of History (Yaounde: Navi-Group Publications).

3. Eyongetah and Brian (1987): A History of the Cameroon (Yaounde: Navi-Group Publications).

4. J.C. Catford (1965): A Linguistic Theory of Transiation (Oxford: Oxford University Press), p. 31.

5. Rev. Jonas Dah (1986): African Responses to Christian Presence (Buea: A Centenary Issue), p. 18.

6. ibid., p. 19.

7. ibid., pp. $18-19$

8. ibid., p. 24 .

9. Bernard Omgba (1985): Histoire de L'Église du Cameroun 1841-1982 (Yaounde: Sopecam), pp. 14-15.

10. Patrice Kayo (1978): Panorama de la littérature camerounaise (Bafoussam: Librairie Panafricaine), p. 30.

11. Rev. Jonas Dah (1986): African Responses to Christian Presence (Buca: A Centenary Issue), pp. 23-24.

12. Patrice Kayo (1978): Panorama de la littérature camerounaise (Bafoussam: Librairie Panafricaine), p. 32.

13. George Steiner (1975): After Babel: Aspects of Language and Translation (London: Oxford University Press), p. 330. 